Law in the Digital Age. 2021. Vol. 2, no. 3.

Вопросы права в цифровую эпоху. 2021. Т. 2. № 3.

\title{
Articles
}

Research article

УДК 340

DOI: $10.17323 / 2713-2749.2021 .3 .3 .32$

\section{The Law of a Technogenic Civilization to Face Technological Dehumanization Challenges}

\section{$\Omega$ 目 Valentina v. Lapaeva}

Institute of State and Law, Russian Academy of Sciences, Moscow, Russia, lapaeva07@mail.ru

\section{間 Abstract}

Law as a regulatory system based on the principle of formal equality in freedom is a social phenomenon immanently inherent in a technogenic civilization with its cultural matrix, in which "gene" of techne (skill based on knowledge) was rooted. The specifics of the current stage in the technogenic civilization development are determined by NBIK technologies, NBIK technologies, which contain not only tremendous opportunities to improve the quality of human life, but also no less large-scale dangers of dehumanization, due to their intentions on the posthuman perspectives. The need to resist the destructive potential of these technologies in order to keep the technohumanitarian balance, which still protects humanity from self-destruction, requires the mobilization of all socio-normative resources, the most important of which is law. However, the problem is modern law, being primarily a system of human rights, is not able to prevent threats to future generations and humanity as a whole. This is especially clearly seen in the example of research and technologies for inherited editing of the human genome, which development cannot be channeled into the mainstream of global legal regulation. The international norms of "soft law" and the world academic community self-regulation can no longer restrain technological expansion into human nature. An attempt to solve the problem along the path of a post-secular turn in the hope that religious consciousness will become that saving spiritual resource, which help humanity to keep its technological power within the proper boundaries, is unlikely to be successful due to the differences in religious anthropologies inherent in different types of religious ideologies. Therefore the task 
is to develop such a new approach to law understanding that goes beyond the technogenic civilization's spiritual matrix, which, on the one hand, would preserve the basic guarantees of individual freedom, and on the other, would integrate the idea of the rights of future generations.

\section{O-1国 Keywords}

law, technogenic civilization, NBIC-technologies, editing the human genome, artificial intelligence, dehumanization, human rights, solidarity, future generations.

For citation: Lapaeva V.V. The Law of Technogenic Civilization to Face Technological Dehumanization Challenges. Legal Issues in the Digital Age. 2021, no. 3, pp. 3-32. DOI: $10.17323 / 2713-2749.2021 .3 .3 .32$

\section{Introduction: concepts and theoretical and methodological basis of the analysis}

The formulation of the subject of the study contains ideas in need of clarification. This first of all applies to the concept of the technology-driven civilization, included by academician Vyacheslav Styopin in his typology consisting of two main types of civilization: traditionalist and technology-driven. The distinctive features of the technology-driven civilization, whose cultural matrix, since its inception, has some sort of techni "gene" (that is knowledge-based creative skills) embedded, include the following: the understanding of human beings as the creators transforming the world around them; the ideal of progress, understood as the priority of innovation over traditions; the approach to nature as the object of transformations and the reservoir of resources for action; the cult of scientific rationality; the ideal of the autonomous personality; the idea of power, not so much as power over other human beings, but as power over natural and social objects [Styopin V.S. 2017: 185].

If one tries to identify among these characteristics the most essential (vital, sense-making) one, this is perhaps "innovativeness [of the technologydriven civilization], [its] perennial and steadily accelerating stream of pioneering research and development projects, which form the basis and matrix of universal changes" [Maslov V.M., 2014: 871-875]. The modern technology-driven civilization, with its tremendous drive for innovation, defines the main development path for humanity - the course of the journey that has been joined, with different degrees of success, by those countries and regions previously had pursued the traditionalist model of civilization. 
Another thing in need of elucidation is the concept of "law," the attempts at theoretical understanding of which have generated a wealth of concepts. This writer will draw on academician Vladik Nersesyants's idea of law as a system of norms epitomizing the ontological legal principle of formal equality - equality of free people [Nersesyants V.S., 2002: 3-15]. It is this approach that has the largest degree of congruity with the social phenomenon that can be defined as law of the technology-driven civilization: a human being's creative freedom is ultimately the main resource for the progress in science and technology. Unlike the other normative systems (moral, religion, customs), which due to their very nature gravitate towards the traditionalist civilization, law, as a measure of a human being's freedom, is a product of the technology-driven civilization, as well as a stimulus for its development and a guarantor of its safety.

The word "technology," too, is often interpreted differently by different parties - its present-day academic usage is very far from the definition proposed in UNESCO's Recommendation on the Status of Academic Researchers (1974), according to which "the word 'technology' signifies such knowledge as relates directly to the production or improvement of goods or services"1. Presently the word "technology" can be applied to all types of human activities (including the social technologies) people can carry on in order to transform or manipulate their surroundings. The present article, however, addresses only the so-called high technologies in the NBIC-convergence framework because it is nano-, bio-, info- and cogno-technologies in their synergetic unity that define the essence and distinctiveness of the present stage of the technology-driven civilization's development.

As for the term "technological dehumanization", because of its conceptual crudeness and the polysemy of the pivotal term "dehumanization" [Haslam N., 2006: 252-264], it needs gnoceological legitimation. The introduction of this term into academic discourse is necessary for gaining a thorough understanding of the qualitatively new, post-human character of the $21^{\text {st }}$-century high technologies, which change not only human beings' surroundings but also human beings themselves - their consciousness and mental and physical characteristics. As they achieve positive results in medical treatment, improving living standards and saving individual lives, in relation to humanity as a whole these technologies, intervening in human subjects, may ultimately produce a considerable cumulative dehumanizing effect.

1 Available at: http://hrlibrary.umn.edu/instree/researchstatus.html; also: https:// en.unesco.org/themes/ethics-science-and-technology/recommendation_science/evolution, https://unesdoc.unesco.org/ark:/48223/pf0000114040.page=166) (accessed: September 29,2021 ) 
Gaining a thorough understanding of law as a phenomenon of the technology-driven civilization should include an analysis of law as the key socio-normative guarantor of safety of technological progress. For illuminating the role and significance of law as an internal protective mechanism of the technology-driven civilization, a useful analytical tool to apply is the concept of techno-humanitarian balance developed by Akop Nazaretyan. According to this concept, the more powerful man-made military and industrial technologies are, the more sophisticated methods of cultural (socio-normative first of all) regulation are needed for preserving the body public. Culture, writes Nazaretyan, "having been tempered in the crucible of dramatic cataclysms, had been improving its tools of control over natural aggressive impulses and so adapted the man to the growing instrumental power." He formulated and tested his idea on the basis of a historical analysis of causes of anthropogenic crises and disasters throughout the history of humankind and on the basis of an estimate of the fluctuations of the fatality rates (that is a proportion between the average number of murders and the population size at a given time period) - these rates steadily dwindled as military technologies became more sophisticated and the population sizes increased. Nazaretyan's analysis shows that societies which managed to mobilize the humanistic elements of reason in order to defuse the destructive potential of anti-humanistic rationality came out winners in historical competition whereas the others "were weeded out of the historical process, as they destroyed the natural and/or organizational foundations of their existence" [Nazaretyan A.P., 2015: 107, 116].

In a situation when "the breath-taking speed of technological development that may very easily run out of control" [Weizsäcker E., Wijkman A., 2018: 6] is becoming, as stated in the anniversary presentation of the Club of Rome, an increasingly more far-reaching and systemic problem of modern society, the vital question is whether the technology-driven civilization is constitutionally capable (or incapable) of handling this problem using its own resources. Because, as civilization evolved - and, concurrently, on the one hand, the need for creative freedom grew, and on the other, the risks of man-made disasters grew as well - law has been assuming, to an ever greater degree, the functions of the regulator, edging out the other socionormative regulatory mechanisms, so the vital question now is this: is it possible, using legal tools, to prevent the consequences of technological dehumanization that pose risks to humanity? So this is the lens through which this writer is going to look at the issue at hand. The main problem, meanwhile, consists in the fact that law, essentially a product of the technology-driven civilization, is the main source of dangers this civilization 
may face. If, according to Gödel's incompleteness theorems, one cannot provide a complete and consistent description of a system staying within this system, the question begs itself: is it possible to solve a system's problem using only this system's immanent resources?

\section{Law as a phenomenon of the technology-driven civilization}

In order to understand the nature of law as a phenomenon of the technology-driven civilization, one should take a look at the origin and development of law. In the context of the issue under review, the main question pertaining to the genesis of law is whether law, at the stage of its gestation, was the result of the man's social creative work (in which case we indeed can claim that law is the product of the creativity- and innovation-oriented technologydriven civilization) or whether it emerged as something "natural," something given from the outside, something basic for that place and time - the element which, as proponents of natural law argue, "is the sole and incontestable primary source of legal meaning and the absolute legal touchstone for all man-made norms, rules and laws" [Nersesyants V.S., 2006: 794].

Addressing the issue at hand, this writer assumes that the approach to law as a special social phenomenon reflecting a certain essentiality implies that law had this essential characteristic already at its inception [Nersesyants V.S. 2006: 63]. This means that (contrary to what is generally assumed) law was not a part of a syncretic monistic norm that spawned the primitive society's system of relations, which included rudiments of law, morality and religion, as well as tribal customs. This view on the genesis of law is corroborated in the works of a number of anthropologists who distinguish law as an essentially social phenomenon from the naturally formed customs regulating the relations of blood kinship. These researchers, moreover, they emphasize a circumstance that is vitally important for our analysis - society and law emerged at the same time. From this vantage point, legal equality was not at all born from "brotherly" distribution of food within a clan but from essentially social mechanisms of containment of sexual instinct, such as the establishment of an intragroup taboo on incest and the enforcement of this taboo by creating a clan consisting of two groups and a system of matrimonial exchanges between these groups, which were, historically, the first subjects of egalitarian social relations ${ }^{2}$.

2 This writer refers to a situation when a clan is divided into two equipollent groups, which develop a practice of swapping so called "marriage partners," mostly brides. 
The first in the history of humankind, this instance of social engineering, which was a product of the colossal exertion of the primitive man's intellect and will, became, according to Lévi-Strauss, a first step in the protohumans' journey from the world of nature to social world: "Prohibition on incest... is the basis of human society" [Lévi-Strauss C., 1985: 19]. The incest taboo was instrumental in protecting the nascent humankind from the danger of self-destruction, which was conditioned by the absence of instinctive jammers of intraspecific aggression ${ }^{3}$ in humans as a distinctive biological species; this taboo also contributed to preventing members of clans from self-destruction in the course of the struggle for satisfying sexual instinct.

Another product of this taboo was the creation of collective subjects of interaction who communicated with each other on a formally egalitarian basis. "Social interactions in the system of two-group clans was based on an equipoise of clans. Preservation of each clan was contingent on preservation of this equipoise. Each clan considered its counterpart as different but equal... No single group knew how to keep another group under its thumb and an attempt to shift the balance so as to benefit one of the clans would have been disastrous for the entire community" [Shalyutin B.S., 2011: 18]. The formation of the two-group clans became the main driving force both in the formation of society (because each of the communities' groups was thus provided with a collective image of the Other necessary for producing the groups' self-identification) and in the formation of law (because in the process of what was essentially law-based exchange the nascent humankind was acquiring and enriching its experience of law-based communication).

Sure enough, the approach to law as the result of human beings' creative efforts to contain the destructive aggression inherent in their biological self should not be understood as a negation of the fact, already proven by biologists [De Waal F., Ober J., 2006: 140-160] and evolutionary psychologists, that empathy and reciprocity became incorporated in human genes in the course of the evolution. Moreover, this genetic predisposition was the source of the capacity for rational, that is consciously reciprocity-based approach to solving problems arising out of conflicts within clans. The mutual penetration of natural and social elements, typical for biosocial evolution, was instrumental in addressing the most difficult challenges of the evolution - on the one hand, it was necessary to preserve humans' intraspecific aggression, the quality which is, according to experts, the key source

3 According to the prominent ethologist Konrad Lorenz, this property of humans as a species could have destroyed them had the human mind not proved itself capable of coping with the dangers associated with this property. See [Lorenz K., 1994: 200-220]. 
of an individual's creative energy, and on the other hand, humans' most dangerous manifestations had to be blocked. From this postulate, however, one cannot infer the natural character of the human rights, contrary to Fukuyama's and other thinkers' argument. In this natural state human beings were not yet different from animals: they became humans precisely through their conscious creative efforts to contain their natural instincts.

Despite the universality of the initial stage of the formation of society and, synchronously, of law, the further evolution of law as a carrier and expresser of human being's creativity proceeded differently in different regions of the world. For a number of historical reasons, societies living by the principle of formal equality of free people were mostly concentrated in Western Europe, where equality contributed significantly to the birth of the technology-driven civilization. Of great importance in the evolvement of the technology-driven civilization was antique philosophy, which laid the foundation of rationalist European culture, with its orientation at people's creative, transformative activity and its Christian spiritual tradition, which "was some sort of a mediating force between antique and new European cultures" [Styopin V.S., 2011: 254].

The key role in the process was played by the Christian dogma, embedded in the West's spiritual matrix, whereby the man was made in the image and likeness of God; in Catholicism, this dogma expressed the man's aspiration to understand God by understanding the man made in His image and likeness. This is a major point of difference between Western theology and the Eastern traditional approach to the dogma about the man's likeness to God - the approach based on the premise "that the Revelation tells us about God and only after this, tells about the man and finds in him that what corresponds with the image God," with the result that the man's image remains "incomprehensible because reflecting the entirety of his Prototype, he also must be as incomprehensible as He is" [Sinelnikov S.P., 2010]. The Catholic idea that God can be comprehended through the man and that it is possible to consider human actions as "some sort of a small-scale reproduction of the acts of creation" [Styopin V.S.: 2011:256] was later developed by Protestant thinkers. In Western societies, these core beliefs contributed to the gestation of the ideas of people's freedom in public life, whereas the Orthodox Christianity catechized the man into the importance of spiritual freedom from sin [Sinchenko G.Ch., 2000: 16].

The Western traditional exegesis of the Christian dogma of the man's likeness to God was reinforced with the belief in rationality of the Creator, "who endowed his Creation with consistent physical laws" [Woods T., 2010: 
87]. And although Peter Abelard's proud statement "I seek to understand in order to believe" - which stood in contrast to the concept "I believe in order to understand," prevalent at his time - was gaining acceptance with difficulty [Levandovsky A.P., 2005: 6-13], ultimately it became incorporated into the West's spiritual matrix, creating a most favorable environment for the development of sciences. Another important factor contributing to the process, and likewise closely related to the mentioned Christian dogma, was the idea of equality of people, understood in a far broader sense than the limited equality of the free citizens of the ancient Greek city-states. This contributed to the significant strengthening of law as a normative regulator based on the principle of equality of free people, and since the start of the modern era law has been steadily sidelining religion and morality in the hierarchy of socio-normative regulators. Law-based path of humanity's development, which was present in social practices and conceptualized in the works of the Modern Era's philosophers, for whom natural law "was already originating not from the universal law of nature or divine reason but from the very nature of the man" [Romashov R.A., 2021: 16], — this law-based path brought human beings the creative freedom necessary for scientific and technical progress and later, for scientific and technological progress.

Law meanwhile not only created an environment suitable for the development of sciences and technologies: performing its initial function, it continued to serve as a safeguard against humankind's self-destruction that could take place in the wake of yet another breakthrough in science and technologies. All through the history of the origination and development of the technology-driven civilization, the growing power of the new technologies was compensated by improvement of socio-normative (first of all religious, moral and legal) regulators, and this preserved the balance between technical and humanitarian elements keeping the civilization from destruction. A good example of such beneficial transformation of socio-normative regulators is the evolvement of religious tolerance in Europe in the aftermath of the Thirty Years' War (1618-1648). Herefrom, according to Paul Ricoeur, originated the ideology of liberalism, which affirms the idea of tolerance, proclaimed in the New Testament by Apostle Paul, "as a positive value of a higher level than religious beliefs, which are different from each other" [Ricoeur P., 2005: 81]. Another equally important result of this lengthy and deadly war was the establishment of the principles known as Westphalian sovereignty, which ushered in the new era in international law. Intrastate social conflicts at that period of the evolvement of capitalism, too, were handled within a legal framework, which facilitated the elimination of class barriers and the release of the creative energies of the nascent bourgeoisie. 
The French Declaration of the Rights of Man and of the Citizen (1789), a milestone in the evolution of law, can also be considered as one of the results of the Thirty Years' War: as Nikolai Berdyaev wrote, quoting Georg Jellinek, "this declaration originated in religious communities of England, begotten of the religious recognition of the freedom of consciousness and the definitive importance of the human individual, who sets limits on any power of the state. From England the Declaration of the Rights of Man and of the Citizen was brought to America and only after it, to France" [Berdyaev N.A., 1990: 288]. As for America, the text in question is the Declaration of Rights, adopted in 1776 by the legislature of Virginia - the document which, in the context of our analysis, merits special attention: proclaiming natural human rights, it is the first historical document bringing up the idea of the rights of future generations, which is receiving the appreciation it merits only now, in the context of the advent of the technologies capable of intervening in human subjects. Section 1 of the Declaration states: “...all men are by nature equally free and independent and have certain inherent rights, of which, when they enter into a state of society, they cannot, by any compact, deprive or divest their posterity..."4 The realization of the ideas set out in these groundbreaking acts of expression of people's will facilitated the evolvement of the modern system of law as a normative form of people's freedom and the evolvement of law-based democracy as an institutional form of freedom: "Sweden in 1809 and Holland in 1815 followed the English model of incorporating the concept of natural rights into the constitution of a monarchy; other nations copied the American model of a republic having the preservation of men's natural rights as its raison dêtre" [Cranston M., 1975: 12].

In the $20^{\text {th }}$ century the system of international law received a powerful stimulus from the two world wars whose experiences were reflected in the Covenant of the League of Nations (1919), the Pact of Paris, otherwise known as the General Treaty for Renunciation of War as an Instrument of National Policy (1928), and the Charter of the United Nations (1945), which formalized the prohibition on war as an instrument of settling disputes and allowed to use the force of arms when sanctioned by the UN Security Council. The deliberations about the anti-legal experience of the totalitarian regimes going on at that time considerably strengthened legal elements in public life and governmental affairs, a process resulting in the adoption of the Universal Declaration of Human Rights (1948) and the related international treaties elaborating on its provisions. Many states

4 Available at https://www.archives.gov/founding-docs/virginia-declaration-of-rights (accessed: January 10, 2020) 
incorporated into their postwar constitutions the array of human rights contained in the mentioned documents. This array is based on the set of humanistic values of natural law, the product of the merging of the antique understanding of law as a just measure-for-measure retribution and the Christian moral idea of justice as mercy ${ }^{5}$. Although the doctrine of natural law by now ${ }^{6}$ has gone through numerous transformations in keeping with the times, it still combines these conflicting regulatory principles ${ }^{7}$.

Up until now humanity, using the international non-proliferation agreements related to nuclear, chemical, biological, radiological, etc. weapons of mass destruction, has succeeded in keeping the situation under control. In the current context, however, these intergovernmental agreements can no longer guarantee security because new actors are getting hold of the technologies of the production of weapons of mass destruction. Technologies are a form of knowledge and skills whose reproduction is much cheaper than their creation. According to scholars of life-saving technologies, this peculiarity makes technologies what might be called a carrier of collective interaction, which becomes the main motor of history [Podlazov A.V., 2018: 39-63]. But this feature also makes these technologies easily available life destruction instruments. This peculiarity becomes especially dangerous in the present context of polarization of wealth ${ }^{8}$, when corporations and even individuals have been given the opportunity to lay their hands on resources which are beyond society's control and which "are just as big as or even larger that the resources controlled by the state".

One of the most vivid examples of this danger is international terrorism. The global terrorism threat presented humanity with a very difficult moral dilemma - on the one hand, there is the idea of law as a form of free-

${ }_{5}$ Tellingly, some Western authors call the rights set out in the Universal Declaration of Human Rights "moral rights" (Cranston M., 1975: 97].

6 "The doctrine of natural rights by now... has shed its excessive axiomaticity and straightforwardness but still has the potential to develop along its traditional lines" [Romashov R.A., 2021: 51].

7 The most vivid example of this is the interpretation of the right to life which rules out capital punishment.

8 "Global income distribution has thus changed in a remarkable way. It was probably the profoundest global reshuffle of people's economic positions since the Industrial revolution... The most interesting developments, though, happened among the top quartile: the top $1 \%$, and somewhat less so the top $5 \%$, gained significantly, while the next $20 \%$ either gained very little or faced stagnant real incomes" [Milanovic B., 2014: 15].

9 “New Rules or No Rules." 11th Annual Valdai Discussion Club Meeting Participants' Report. Available at: https://valdaiclub.com/a/reports/new_rules_or_no_rules_xi_annual_valdai_discussion_club_meeting_participants_report/ (accessed: September 29, 2021) 
dom inherent in the spiritual matrix of the technology-driven civilization, and on the other, there is the need to limit this freedom for security's sake. Whereas previously this perennial problem of humankind was handled by separate players on their own terms, in the modern society of global risk its handling became very much a public legal matter. The question in need of an answer, meanwhile, is this: in order to guarantee safety of those who are averse to risks, is it justified to limit the freedom of those who are willing to risk their safety for the freedom's sake? Its implications reaching far beyond the problem of terrorism, this question, which modern society has yet to answer, has taken on special urgency in the context of COVID-19, when humankind has to decide whether one should "exchange health protections for basic rights," ${ }^{10}$ if what is at stake is far more than one's own health.

In the context of our analysis, the most interesting aspect of the problem of legal regimes during a pandemic is not so much the lockdowns (on which most legal debates has been focused) but the extensive use, by the states, of digital tracking of contacts and digital observation of citizens' health. And since it has been discovered that such form of control is simple and efficient (the People's Republic of China has gone especially far along this path), there is a danger that these practices will remain a norm even when the COVID-19 pandemic is over. The need to address this danger for the sake of protecting human rights and freedoms was brought up, in particular, in the Joint Statement on Data Protection and Privacy in the COVID-19 Response, issued on December 18, 2020, and signed by several UN organizations ${ }^{11}$.

The pertinence of this formulation of the problem was demonstrated especially clearly in the book "COVID-19: The Great Reset," a treatise coauthored by the World Economic Forum's founder Klaus Schwab and released at the height of the pandemic: the authors argue that even when the pandemic is over, "nothing will ever return to the 'broken' sense of normalcy that prevailed prior to the crisis because the coronavirus pandemic marks a fundamental inflection point in our global trajectory... the world as we knew it... is no more, dissolved in the context of the pandemic" [Schwab K., Malleret T., 2020: 11]. According to Schwab, who is one of the world's most influential experts, the pandemic is a "window of opportunities" for creating a new world where nation states will be replaced with

${ }^{10}$ Cortés-Arbeláez A. Pandemic and States of Emergency: A Comparative Perspective. 2020. May 22. Quoted: [Varlamova N.V., 2020: 25].

11 Available at: https://reliefweb.int/report/world/joint-statement-data-protectionand-privacy-covid-19-response (accessed: September 29, 2021) 
transnational companies, which, Schwab believes, will carry the bulk of social responsibilities. Klaus Schwab's previous tome, "The Fourth Industrial Revolution," in which he shows himself not only as a globalist but also as a transhumanist, gives us a good idea of the type of world that is supposed to be built after the "great reset" (or, in a more apt translation suggested by some, "the great resetting of the counter to zero"). The pandemic, Schwab argues, has accelerated the transition of the technology-driven civilization to the fourth industrial revolution with its convergence of NBIC technologies, promising radical changes to humankind.

Called by many a globalism manifesto, this book appears to have marked the beginning of a qualitatively new stage of the late modernity, straightforwardly outlining the ominous contours of a post-human reality that may arrive in the foreseeable future. Another development of the last decade, looking equally ominous in the context of our analysis of the genesis of law, has received much less notice globally. In 2014 Germany's National Ethics Council recommended that the ban on incest be lifted, arguing that "the fundamental right of adult siblings to sexual self-determination is to be weighed more heavily than the abstract idea of protection of the family." ${ }^{12}$ The matter at issue here of course is not the call to lift a criminal ban on incest (in many countries incest is not regulated by criminal legislation) but the argumentation aimed at convincing the public of social acceptability of the elimination of the age-old taboo which once set in motion social history of humankind. This approach, designed to destroy the institution of the family, has a dehumanizing potential because the family is the place where people restore their psychological resources necessary for preserving the potential of humaneness which so far has kept humankind from self-destruction. The fact that this issue has been broached now is probably not accidental: destruction of the foundation built by evolution into human civilization is one of the preconditions for transition to a post-human future.

\section{Law and the challenges of the technology-driven civilization}

For all the seriousness of the abovementioned problems, which arise as destructive technologies evolve, humankind so far has been able to preserve the vital balance between technological and humanitarian elements, in large measure because the risk of humanitarian element being margin-

12 "Incest Ban at Odds with Sexual Self-Identification" (Zapret intsesta narushaet pravo na seksual'noe samoopredelenie). Available at: URL: https://russian.rt.com/article/51928 (accessed: February 5, 2021) 
alized was obvious. The $21^{\text {st }}$-century newest NBIC technologies, however, are first of all creative, rather than destructive, technologies, the ones that give people hope for overcoming the environmental crisis, transitioning to personalized medical care, increasing life expectancy, advancing in most diverse spheres that use artificial intelligence technologies, becoming capable of creating a new world through controlled manipulation of atoms and molecules and of improving the quality of individual and public consciousness, etc. - all these alluring prospects serve to obscure the posthuman nature of these technologies which are, in essence, "forms, methods for putting post-human into practice" [Maslov V.M., 2014: 872].

Although many of the posthuman applications of NBIC technologies are yet theoretical, there are already some alarming episodes of their practical application. Thus, the prospect of organ printing from stem cells utilizing $3 \mathrm{D}$ nano-printing technologies is still a theoretical option but nanorobots in medicine are already a reality, so the anxieties about their possible unsanctioned incorporation into human organisms are not unwarranted. The technologies of genome editing of embryos, as was noted by one of the creators of the method and Nobel Prize winner Jennifer Doudna, still cannot make "the designer children" intelligent and good-looking, although even now they can be used for augmenting an organism's endurance, developing the capacity for sleeping less than usual, etc. ${ }^{13}$ - enhancing the qualities giving a competitive edge in life. Similarly, one can say that although neurotechnologies still cannot control what is going on in the brain, brain scans can expose individuals' political orientation - show whether it is liberal or conservative - with more than 70\% accuracy [Kosinski M., 2021]. And it is not only states but private persons as well who can become digital dictators utilizing these innovations.

Besides, in the foreseeable future control over information, as was noted by Israeli historian Yuval Harari in his presentation at the World Economic Forum, will enable the world's elites to do something more radical and dangerous than establishing a digital dictatorship: biological engineering and information technologies will make them better informed about any single individual than this individual's family. "If these matters are not regulated, a tiny group... will set the course of life on the Earth." ${ }^{14}$ Because presently the practical post-human potential of NBIC technologies is most obvious-

${ }_{13}$ Available at: URL: https://batrachospermum.ru/2020/10/daudna-genomes-ethics/ (accessed: September 29, 2021)

${ }_{14}$ Available at: URL: https://trends.rbc.ru/trends/futurology/5e2ef4499a79474925ac df08 (accessed: January11, 2021) 
ly realized in artificial intelligence technologies (which experts consider as metatechnologies of the NBIC complex) and in human genome editing biotechnologies, this writer wants to take a close look at these fields of modern technoscience. "Artificial intelligence" (AI) refers to "technological systems which have the capacity to process information in a way that resembles intelligent behavior, and typically includes aspects of reasoning, learning, perception, prediction, planning or control"15. It is generally considered that there are three dangers of dehumanization associated with AI: humans losing control of AI; the likelihood of creating an AI programmed to deliberately cause harm; the risk of discrimination against different social groups - discriminating patterns can be built into "algorithms by reflecting (intentionally or not) the programmers' prejudice ${ }^{16}$ or discriminatory stereotypes inherited from predecessor software" [O'Sullivan S., 2019: 9].

When considered individually, each of these risks does not seem very threatening, and yet, a combination of them in a technology can be threatening to the very foundation of human coexistence. AI emotion recognition technologies are one such example. As demonstrated by China's experience, which was analyzed recently in a report of British human rights group Article 19, the introduction of these technologies starts with such seemingly innocuous projects as assistance to law enforcement ${ }^{17}$, but very quickly the scope of use expands under the enormous pressure of interested parties such as the government and businesses.

For all the abundance of public and academic discussions of ethical and legal aspects of $\mathrm{AI}$ - and this subject has grown in prominence in recent years - experts note that the current global problem is "the practically complete absence of legal and technical regulation of the basics, conditions and distinctive features of the research and development, launch, function-

${ }^{15}$ First Draft of the Recommendation on the Ethics of Artificial Intelligence (I(2)), prepared by UNESCO's expert group, in line with the decision of UNESCO's General Conference at its 40th session (40 C/Resolution 37), in March 2020. Available at: https://unesdoc. unesco.org/in/documentViewer.xhtml?v=2.1.196\&id=p::usmarcdef_0000373434\&file=/ in/rest/annotationSVC/DownloadWatermarkedAttachment/attach_import_0982366e6c20-418f-9317-c09866b9b0e9\%3F_\%3D373434eng.pdf\&locale=ru\&multi=true\&ark=/ ark:/48223/pf0000373434/PDF/373434eng.pdf\#page=1\&zoom=auto,-16,850 (accessed: September 29, 2021)

16 Thus, a significantly larger share of males among software developers can result in the creation of software which latently discriminates against females.

17 Emotional Entanglement: China's emotion recognition market and its implications for human rights. Published by ARTICLE 19 in January 2021. London, 2021. P. 18. Available at: https://www.article19.org/wp-content/uploads/2021/01/ER-Tech-China-Report. pdf. (accessed: April 16, 2021) 
ing, integration with other systems, and control over the utilization, of AI technologies [Ponkin I.V., Redkina A.I., 2018: 93]. Moreover, appropriate international ethical recommendations have yet to be produced. This is why in March 2020 UNESCO set up a group of experts, which by September 2020 produced a first draft of recommendations on ethical aspects of AI. Remarkably, the text in question is not a normative legal document but only a recommendation focused on AI's ethical aspects: the text's authors emphasize that this is only a framework document, which "finds its basis in ethics, as well as human rights [and] fundamental freedoms."

As it appears, the actors who initiated the creation of these recommendations took into consideration the long experience of working on ethical and legal regulation of genome technologies - an undertaking that has yet to produce a global legal act, although the creation of such instrument was declared as a goal already at the initial stage of the international Human Genome project. But for all the importance of the challenges related to AI technologies, as Yuval Harrari noted, these technologies are "just stimulants for your imagination. What we should take seriously is the idea that the next stage of history will include... fundamental transformations in human consciousness and identity. And these could be transformations so fundamental that they will call the very term 'human' into question" [Harari Yu., 2019: 491]. Genome editing technologies, which even now can directly intervene in human subjects, carry the most obvious risks of dehumanization. Interestingly, modern neo-Marxists invoke these technologies in their analyses of the essence of the present stage of capitalism, whose main distinction is the fact that knowledge, at this stage, is regarded already not as an instrument of production but as means of reproduction of biological and social life $\mathrm{e}^{18}$.

The world's leading geneticists, who once initiated the international project of human genome sequencing, took great efforts to set in place a system of socio-humanitarian guidance for their research. Moreover, beginning from the 1980s, that is concurrently with the start of the international Human Genome Project, the Council of Europe developed and adopted a series of recommendations on genetic engineering, on utilization of embryos and human biomaterials for diagnostic, therapy and scientific research, on genetic testing for medical purposes, etc. These recommendations were later used in the preparation of the text of the Convention for

18 The situation when capital controls knowledge, writes Antonella Corsani, "can ultimately lead to the situation when it is possible to decide whether or not to grant the right to live. Pharmaceutical industry, for instance, prefers research into rejuvenation methods to fight against tropical diseases" [Corsani A., 2007: 130]. 
the Protection of Human Rights and Dignity of the Human Being with regard to the Application of Biology and Medicine (hereinafter referred to as the Convention on Human Rights and Biomedecine), which was opened for signature in 1997. Later, however, only three binding protocols complementing the Convention were adopted ${ }^{19}$ while the rest of international documents in this area are "soft law," that is texts of a declarative and recommendatory nature ${ }^{20}$.

The attempts to direct along legislative lines socio-normative regulation in the area of human genome editing research and clinical trials have faced serious resistance due to the differences in sociocultural traditions in different regions of the world (first of all the differences in religious anthropology, the most vivid example of which is different interpretations of the ontological status of human embryos), as well as the extraordinarily fierce competition in this field: countries compete for biosafety and their citizens' living standards; transnational corporations compete for markets for drugs and technologies; and scientists compete for scholarly prestige. It is precisely the striking advances in human genome editing made by Chinese scientists that caused British authorities in 2016 to allow genome editing of 2-week-old human embryos in vitro, provided they would not be implanted into a woman's body.

The desire to keep up with the competition undoubtedly played some role when Britain's Nuffield Council on Bioethics (a civic organization respected in the academe) published in 2018 a report stating that heritable genome editing interventions may be allowed, provided they are "consistent [with] the welfare of the future person; and they should not increase disadvantage, discrimination or division in society" ${ }^{21}$. Some experts, meanwhile, believe that the report "leaves open the possibility that such technologies could be misused for cosmetic purposes" and "breaches an international consensus in a way that increases the risks of irreversible genetic alterations and new forms of inequality" [Dickenson D., 2018].

${ }_{19}$ Additional protocols on human cloning ban (Jan. 12, 1998), biomedical research (Jan. 25, 2005), and genetic testing for health purposes (Nov.27, 2008).

20 This is first of all the Universal Declaration on the Human Genome and Human Rights (1997), International Declaration on Human Genetic Data (2003), United Nations Declaration on Human Cloning (2005), Universal Declaration on Bioethics and Human Rights (2005), as well as documents of the World Health Organization, World Medical Association, Council for International Organizations of Medical Sciences (CIOMS), Committee on Ethics, Law and Society of the Human Genome (HUGO) organization.

${ }^{21}$ Genome Editing and Human Reproduction: Social and Ethical Issues. Published July 17, 2018. Available at: https://www.nuffieldbioethics.org/publications/genome-editing-and-human-reproduction (accessed: July 5, 2021) 
Important regulatory instruments in the area of genome research and technologies include self-regulation mechanisms of the international academic community - they complement the global "soft law." They include editorial and financial policies of leading science journals and foundations (whereby articles and grant proposals should be accompanied with a confirmation of their conformity with the recommendations of international scientific organizations), opportunities for researches to participate in international collaborative projects, to have their achievements recognized by their peers, etc. Reality, however, has demonstrated the unreliability of all present instruments of global governance. The arrival of a pair of geneedited twins in China (just several years after 2012, when the genome editing technology CRISPR/Cas9, used in the production of the twins, was created) showed one more time that technologies are an easily reproducible form of knowledge and skills.

When the huge material resources contributed by different countries and the colossal efforts made by global scientific community produced great results in the areas of DNA decoding and human genome sequencing and, finally, in creating, using all this knowledge, an effective genome editing technology (an accomplishment crowned with the Nobel Prize in chemistry in 2020), it became obvious that it would be very difficult (or maybe even impossible) to keep in check the spread and utilization of this technology in a field so dangerous as human germline editing. The Chinese experiment has met with unanimous opprobrium among geneticists and bioethicists, although the reasons for the negative reactions differ: some experts consider human germline editing unacceptable in principle while others criticize the experimenters only for taking an excessive risk and insufficiently substantiating the medical necessity of the venture. And there are nuances of opinion inside each of the two camps.

The experts who consider human germline editing acceptable include both entrenched transhumanists and those who hope that genome therapy would not be used for "improving" humans or expect that genetic engineering will be used to make humankind more humane (a prospect which, if not utopian, is very dangerous ${ }^{22}$ ). Their opponents advance two very se-

${ }^{22}$ In the discussions about the possibility of such "moral engineering," which by now have been going on for quite a long time in the West, some participants express concern that if humanity does not accelerate the pace of its moral improvement, it will not be able to handle the dangerous consequences of its technological power. However, as Ye. G. Grebenshchikova notes, "might it not become a beginning of the journey in which behavior and social communications will turn out to be just 'technicalities"' [Grebenshchikova Ye. G., 2016: 37]. 
rious arguments mentioned above. The first one: modern people have no right to make, on behalf of all future generations, such existential decisions, which can cause irreversible genetic transformations. The second argument grows from the concern that this path will lead to unmanageable social inequality both inside individual states and globally [Darnovsky M., 2008: 453]. This inequality can be of such magnitude and nature that humankind would eventually become split into different sociobiological castes.

The argument that benefits of technological progress are always enjoyed first by elites and only then by everybody else does not seem convincing: it was true in the era when elites were interested in the masses as labor or cannon fodder. It was by virtue of this interest shared by the masses and elites alike that "the great human projects of the twentieth century - overcoming famine, plague and war - aimed to safeguard a universal norm of abundance, health and peace for all people without exception. The new projects of the twenty-first century... aim at surpassing rather than safeguarding the norm, they may well result in the creation of a new superhuman caste" [Harari Yu., 2019: 103], a caste which will not be interested in raising living standards of the rest of the populace to its level. We can see how modern medicine is increasingly more preoccupied with making the rich and the healthy look younger and more beautiful, siphoning off resources from healthcare for the poor and the sick. Similar trends are emerging already in the area of genome editing: thus, three-parent fertilization method - when the damaged mitochondria in the mother's egg is substituted with healthy mitochondria from another woman's donor egg ("three-parent babies" in common parlance) - was developed for families with hereditary diseases but now is being more and more often promoted as a method for overcoming infertility induced by ageing processes [Dickenson D., 2018]. And this is just a beginning.

So, modern law, which is first of all about the rights of an individual, will it be able to counter such a development, which can cause humanity to lose its biosocial unity, with all the disastrous social and biological consequences such a situation may entail (and perhaps for all humanity, not just for future "plebeians")?

\section{Objective difficulties in addressing the problems of technological dehumanization along legal lines}

The question asked should probably be answered in the negative. It is not just that national and international legislative processes are mostly controlled by political and economic elites who will use their leverage to ad- 
vance their interests, that is without any concern for interests of the others. Even if the situation is to evolve within the bounds of law (by which this author does not mean abuses of power under the guise of lawfulness), one should acknowledge that law as a system of norms guaranteeing formal equality of free individuals is underpinned by a logic that is not conducive to solving universal problems of technological dehumanization. Let's consider this thesis in relation to the prospects of utilization of heritable human genome editing technologies.

Here we can clearly see how an advancement along essentially legal lines sets the stage for clinical use of human germline editing with all its dangerous consequences. Thus, according to Art.12 (1) of the International Covenant on Economic, Social and Cultural Rights (1966), each has the right "to the enjoyment of the highest attainable standard of physical and mental health," whereas the Covenant's Art.2(2) guarantees the exercise of this right "without discrimination of any kind." Similar provisions can be found, often in a more detailed form, in constitutions and laws of practically all the modern states. This means that if a person is denied the chance to give birth to a healthy child on account of the legislative ban on human germline editing, (s)he can take legal action complaining about discrimination based on the difference between his/her genetic heritage and the heritage of those who can receive somatic gene therapy (that is gene therapy not using stem cells). The share of such patients will be small because in most cases genetic disorders in fetuses can be treated with ancillary reproductive technologies, without resorting to genetic engineering; this, however, would not change anything from legal viewpoint - all individuals have equal rights (that is rights that do not depend on their genetic status) to healthcare.

So, in such situations Russian citizens may appeal to the Constitutional Court of the Russian Federation arguing that the legislation preventing them from receiving medical treatment using genome editing technologies contravenes provisions of the Constitution: Art. 41(1), guaranteeing healthcare, and Art. 19 (2), guaranteeing "the equality of rights and freedoms of man and citizen, regardless of sex, race, nationality... [and] other circumstances." If the Constitutional Court accepts the complaint, it will most likely refuse to satisfy it evoking Art.55(3) of the Constitution, whereby "the rights and freedoms of man and citizen may be limited... [when] it is necessary for the protection of" certain values of the common good. The Court, in all likelihood, would reference such value as morality (because the other values mentioned in this article obviously have no bearing on the problem at hand). But how one can prove that genome editing for medical purposes is immoral, especially when the advantages enjoyed due to the 
therapy "here and now" would be greater than the risks for future generations' health? For morality is first of all humane treatment of a suffering person.

Anyway, references to the need to protect morality would not do away with the issue of discrimination in healthcare which the complainant has brought up, so his/her next step can be appealing to the European Court of Human Rights (ECHR) with a complaint about the breach of Article 14 of the European Convention for the Protection of Human Rights and Fundamental Freedoms (1950), which forbids discrimination on any grounds. If, reviewing this complaint, the ECHR will bring up (as is its customary practice) the Convention of Human Rights and Biomedicine, it will have to grapple with its inconsistencies. As member of the European Group on Ethics in Science and New Technologies and former Chair of the Nuffield Council on Bioethics Prof. Jonathan Montgomery justly noted, Article 13 of the Oviedo Convention, which forbids interventions in human genome intended "to introduce any modification in the genome of any descendants," is at variance with Article 2 of the Convention, whereby "the interests and welfare of the human being shall prevail over the sole interest of society or science," with Article 3 of the Convention, which guarantees equal access to healthcare services, and with Article 11 of the Convention, which prohibits "any form of discrimination against a person on grounds of his or her genetic heritage" [Montgomery J., 2018: 39-40]. Apparently, Articles 2, 3 and 11 of the Convention, taken together, legally outweigh Article 13 and can, so to say, undo it.

As for the Convention's Article 26, which sets out criteria and reasons for restricting the use of the Convention's provisions on rights and protection, it states that "no restrictions shall be placed on the exercise of the rights and protective provisions contained in this Convention other than such as... are necessary... for the prevention of crime, for the protection of public health or for the protection of the rights and freedoms of others." ${ }^{23}$ Public health, evoked here as the common good, could hardly be interpreted as health of future generations (even in the context of the Preamble stating "that progress in biology and medicine should be used for the benefit of present and future generations").

It follows from here that remaining within a legal framework, we can find ourselves in a situation when good intentions and well-meaning ac-

${ }^{23}$ Convention for the Protection of Human Rights and Dignity of the Human Being with regard to the Application of Biology and Medicine: Convention on Human Rights and Biomedicine. Oviedo, Apr. 4, 1997. 
tions will pave the way for colossal unlawful privileges of people with improved genes and, accordingly, for colossal discrimination against those without ones. Prominent German philosopher Hans Jonas in his book "The Imperative of Responsibility: In Search of Ethics for the Technological Age" 24 argued that a solution to this problem can be found along the lines of the new ethic of responsibility, which would depart from the principle of reciprocation requiring that my responsibility would mirror someone else's right. Essentially, what is suggested is that in the system of socio-normative regulation the categorical imperative of preserving humankind should take precedence over Kant's categorical imperative, which currently sets the parameters for the legal system ${ }^{25}$. "For me... this imperative is the only one which really fits the Kantian sense of the categorical, that is, the unconditional. Since its principle is not... the self-consistency of reason giving to itself laws of conduct... but is rather the idea of possible agents in general, for whom it claims that such ought to exist and is thus ontological, that is an idea of being - it follows that the first principle of an 'ethic of futurity' does not itself lie within ethics as a doctrine of action... but within metaphysics as a doctrine of being, of which the idea of Man is a part" [Jonas $\mathrm{H}$., 2004: 62].

So, Jonas assumes that setting limits to biotechnological development which is something he wants to achieve - cannot be solved using inner resources of the technology-driven civilization since in the final analysis these resources are always used to realize this civilization's built-in intent to conquer nature and control it through machinery. Approaching the problem from the viewpoint of metaphysics as the teaching of transcendent, ontological foundation of being, he proposes that the socio-normative system of the technology-driven civilization be guided by the doctrine "the man must exist." That said, the man, Jonas emphasizes, must not simply exist but must preserve himself in his "uncurtailed being". The categorical imperative suggested by Jonas is not a Kantian normative principle but rather a commandment, whose religious essence Jonas summarized, in the form of a question, as follows: shall we succeed in restoring the category of holiness, which was destroyed by scientific enlightenment, and again instill in the man reverence towards that "what cannot be desecrated under any circumstances" [Jonas H., 2004: 226]?

${ }^{24}$ In this book, published in 1979, that is long before "the era of genetics," Jonas was one of the first to contemplate possible dangers of genetic intervention in human subjects.

${ }^{25}$ From the viewpoint of the understanding of law on which our analysis is based, the Kantian categorical imperative expresses precisely legal, not moral, principle of formal equality [Nersesyants V.S., 2006: 623]. 
Sure enough, in some very distant future, when preserving people's welfare in their "uncurtailed" humanness will become impossible, people will have to go far improving that what nature gave them, if they are "to go beyond our fragile planet, as well as our fragile nature" ${ }^{26}$. Presently, however, embracing the ethic of responsibility, we should slow down the dangerous advancement until technological progress becomes free of existential anthropological risks. From this point of view, it appears advisable to heed the proposal of several leading geneticists and introduce a five-year moratorium on research into germline editing. An expert panel set up by the WHO in 2019 to study scientific, ethical, social and legal problems of human genome editing, however, did not endorse the idea of the moratorium (perhaps because of its unfeasibility) and only recommended "setting up a public registry for genome-editing experiments," developing standards for such experiments and setting in place mechanisms of control ${ }^{27}$.

The realization of even this, very soft scenario of regulating the field will in large measure depend on the goodwill of the subjects of the regulation, which include national governments, national and transnational pharmaceutical companies, research collectives, sponsors of research, and individual scientists.

Because at the end of the day it is always individuals who are the carriers of will, it is important to remember that their will (first of all the will of researchers, whose personal morality theoretically could resist the pressure of governmental and commercial interests) is severely circumscribed by laws concerning state and commercial secrets. In these circumstances, one can find it very difficult to act in line with UNESCO's recommendations that states need to ensure the freedom for scientists to "express themselves freely on the human... value of certain projects and in the last resort withdraw from those projects if their conscience so dictates" 28 . So, here too law does not contribute to containing the dangerous technology trend.

As it appears, Jürgen Habermas, realizing that the technology-driven civilization's problems discussed here cannot be solved within the paradigm of legal rationality, in 2001 advanced the idea of post-secular soci-

${ }^{26}$ From a presentation of English philosopher John Harris at one of the forums on bioethics [Yudin B.G., 2016].

${ }^{27}$ Editorial. Human germline editing needs one message. Science academies and the World Health Organization must act in unison // Nature. 2019. N 575, pp. 415-416. Available at: https://www.nature.com/articles/d41586-019-03525-0 (accessed: September 29, 2021)

${ }^{28}$ Recommendation on the Status of Academic Researchers, UNESCO (1974). Available at: http://hrlibrary.umn.edu/instree/researchstatus.html (accessed Sept. 29, 2021) 
ety (indicatively, his public lecture when he first articulated this idea took place at the time he was finishing his book "The Future of Human Nature"). The essence of the post-secular turn heralded by Habermas is "an unfair exclusion of religion from the public sphere," which "cuts off secular society from important resources of meaningfulness" which religion possesses [Habermas Yu., 2001]. However, there is yet no reason to believe that religious consciousness can become the vital spiritual resource which would help humanity to contain technological progress within safe boundaries. And one can see the unreasonable optimism of these expectations especially clearly in human genetics, where the utilization of human genome editing technologies is a competition space for different traditions of religious anthropology related to different ideas about the nature of the man and, therefore, about possibilities and limits for intervening in it.

The main stumbling block here are the question when conception occurs and the problem of the ontological or (as some would put it) legal status of the human embryo in vitro (that is an embryo outside the woman's body). The most lenient laws regulating manipulations with in vitro embryos exist in technologically developed countries dominated by Buddhism, Islam, and Judaism, and the harshest ones, in European countries with the wellestablished Christian traditions (Ireland, Germany, Italy, Switzerland), as well as in countries who signed the American Convention on Human Rights. In Christian cultural tradition, the embryo has the right to life from the moment of conception because this is when a person's soul is born. It is true, though, that opinions differ over the in vitro embryo: some believe that the soul is born already at the instant of insemination (and, accordingly, the in vitro embryo has the right to life as well ${ }^{29}$ ) while others argue that the conception takes place only when the embryo is implanted in the uterus ${ }^{30}$. In Islam, a human life begins in the $9^{\text {th }}$ week after the conception, when an angel breathes soul into the embryo. And since Buddhists do not have the idea of a soul, they do not attach much importance to this question.

So, Christianity, which was once the crucial force in the formation of the technology-driven civilization, from day one had ideological checks serv-

${ }^{29}$ Such opinion was advanced, for instance, by Dmitry Dedov, judge from the Russian Federation at the European Court of Human Rights. See: Concurring opinion of judge Dmitry Dedov. Application no. 464470/11, Parrillo v. Italy. ECHR Judgment of Aug. 27, 2015.

30 Artavia Murillo et al v. Costa Rica. The November 2012 decision by the InterAmerican Court of Human Rights. 2020. Available at: https://www.womenslinkworldwide.org/files/462/progreso-en-la-proteccion-de-los-derechos-reproductivos-de-las-mujeres-en-latinoamerica-solo-en-ingles.pdf (accessed: April 16, 2020) 
ing to curb the dangerous tendency of technologies to change the nature of human beings. Absent in the world's other religions, these checks continue to exercise considerable influence on the professional ethos of the academic community working within the sociocultural paradigm that grows from Christian worldview. It is obvious that there is little reason to hope to achieve in the foreseeable future a global moral and religious consensus over such questions, which are rooted deep in religious anthropology. Besides, nowadays the road to a consensus in this field is further hampered by the fact that the countries with softer religious prohibitions in human genome research and technologies enjoy significant advantages in global competition. Maybe in the future humanity, having got a taste of post-human reality, will find the strength to consolidate around the idea of the new ethics, which would bridle humanity's technological might.

Presently, however, one should seek solutions to the problem within legal frameworks, expanding their traditional boundaries by introducing the idea of legal responsibility towards future generations. It is noteworthy that although Jonas believed that references to the rights of future generations lie outside the legal regulation paradigm, the regulatory impact of the new categorical imperative proposed by him would be directed not so much at the metaphysical "depths of individuals' moral motivation as at public politics and [this imperative] implies shared responsibility for results of collective actions" [Gadzhikurbanova P.A., 2003: 171], and these collective actions are possible only when something like the social contract, concluded within a legal framework, is in place. It is also very telling that the attempts to reach an interfaith consensus in the declaration on global ethic ("Towards a Global Ethic: An Initial Declaration of the Parliament of the World's Religions"), proposed by Swiss theologian Hans Küng and discussed by the Parliament of the World's Religions in 1993, likewise were focused on seeking a consensus on the basis of essentially legal principles whereby: "every person [must be] treated humanely" and "we must treat others as we wish others to treat us" 31 .

Working on a legal solution to the problem at hand, one can draw on the experience of global philosophy in elaborating a global environmental ethic predicated on the idea of solidarity of generations. In Russian scholarship, this experience was analyzed by A. V. Prokofiev, who identified three major theoretical models of ethic vis-à-vis future generations: contractual,

31 Toward a Global Ethic: an Initial Declaration of the Parliament of the World's Religions. Available athttps://www.global-ethic.org/declaration-toward-a-global-ethic/ (accessed: September 29, 2021) 
utilitarian, and intuitionist. As Prokofiev shows, the contractual model, the closest one to legal approach, does not work due to the already mentioned one-sidedness of intergenerational dependency. As for the utilitarian mod$\mathrm{el}$, its sustained realization would call for excessive sacrifices on the part of present-day generations for the sake of countless descendants. According to Prokofiev, the most promising approach is the intuitivist one, whereby the rights of future generations are not based on a contract but inferred from intuitive ideas about fundamental ethical equality of people [Prokofiev A.V., 2013: 78-93].

The intuitivist approach to setting out the rights of future generations is elaborated by E.Weiss, who argues that "members of the present generation have an intergenerational right of equitable access to use and benefit from the planet's resources, which derives from the underlying equality that all generations have with each other in relation to their use of the natural system" and "each generation is thus both a trustee for the planet with obligations to care for it and a beneficiary with rights to use it"32. In the context of our analysis it is important to emphasize that Weiss's thesis is in line with Article 1 of the Universal Declaration on the Human Genome and Human Rights: "The human genome underlies the fundamental unity of all members of the human family... [and] is the heritage of humanity." ${ }^{33}$ The fact that the human genome is a legacy passed on by previous generations to present generations as a single collective subject was also reflected in UNESCO's "Declaration on the Responsibility of the Present Generations Towards Future Generations," which states that the human genome "must be protected." So, the human genome is recognized is a common heritage to which present and future generations are equally entitled. Such approach arguably implies that future generations should be regarded not as a community that prevails over present generations but as a separate subject (abstract individual) with a vulnerable status and in need of additional guarantees that its interests would be taken into account in the same way as interests of other subjects of law are, on the basis of the principle of formal equality.

${ }^{32}$ Weiss E. Intergenerational Equity: A Legal Framework for Global Environmental Change // Environmental Change and International Law: New Challenges and Dimensions. 1992. Available at: http://www.nzdl.org/cgi-bin/library.cgi?e=d-00000-00---off-0aedl--00-0----0-10-0---0---0direct-10---4-------0-11--11-en-50---20-about---00-0-1-00-0-011-1-0utfZz-8-00\&cl=CL1.1\&d=HASH01e262d576f8179e3bed95ea.8.3\&gt=1 (accessed: Sept. 29, 2021). Quoted: [Prokofiev A.V., 2008: 247].

${ }_{33}$ Universal Declaration on the Human Genome and Human Rights. Available at: https://www.ohchr.org/en/professionalinterest/pages/humangenomeandhumanrights. aspx (accessed: September 29, 2021) 
Another path to legal solutions for the discussed problem can be connected to the new legal construct proposed by scholars championing the introduction of responsibility for parents who agreed to have their offspring genetically modified - this legal innovation would enable "children, grandchildren and other direct kin of the subject with edited genome" to sue such parents seeking financial compensation [Trikoz Ye. N., Mustafina-Bredikhina D.M., Gulyaeva Ye. Ye., 2021: 83]. The legitimacy of this approach has been demonstrated by recent international case law, which includes legally similar suits of disabled children against doctors and parents who in the past chose not to heed the advice to terminate the pregnancy. A new legal term "wrongful life" was coined and is now used is courts [Zakharova M., Voronin M., 2018], making a moral and religious issue a legal one.

In view of the above, it should be also noted that the UN's Committee on the Rights of the Child since 2014 has the right to review complaints lodged by minors who consider themselves victims of a breach of the Convention on the Rights of the Child by a state ${ }^{34}$, including Article 6(2) of the Convention, whereby "States Parties shall ensure to the maximum extent possible the survival and development of the child." At the present stage of affairs, for the want of better options, the prosecutor's office can use its right to initiate court proceedings to protect the right to life and health of "public at large," including into this group future generations: several Russian civil law experts propose this approach in relation to human cloning prohibition [Bogdanov Ye.Ye., Maleina M.N., Ksenofontova D.S., 2020: 134].

\section{Conclusion}

As the matters stand, there is only a slim chance that humanity will come up with an adequate answer to the challenges of technological dehumanization. The magnitude and the impact of the consequences of uncontrolled technological expansion into human nature are so great that not a single social group associated with political and economical, intellectual and spiritual elites of society can assume responsibility for decision-making in this area. And it would be all the more unacceptable to let these processes evolve at random (as largely is the case now).

A lot of international declarations, recommendations, etc. emphasize the need for an inclusive public debate about the risks posed by the newest

${ }^{34}$ Optional Protocol to the Convention on the Rights of the Child on a Communications Procedure. 2011. Available at: https://treaties.un.org/pages/ViewDetails. aspx?src=TREATY\&mtdsg_no=IV-11-d\&chapter=4\&clang=_en $($ accessed: September 29, 2021) 
technologies and for charting future paths for technology that would be acceptable for all humankind; relevant provisions are contained in a number of international legal instruments. The realization of this advice, however, "will necessitate... hard work... and significant human and financial resources" [Andorno R. et al., 2020: 3]. Failing this, humanity will end up not with "communicative rationality" functioning within the Habermasian consensus-oriented rational discourse but with self-contradictory public opinion that will become an easy target for the manipulators owning global financial resources and pursuing their personal interests. In a situation of existential choice, the transformation of society into a real decision-maker requires new institutions for shaping and expressing society's political will. This is probably what Habermas meant writing that "in the face of a globalisation which is taking place over markets from which borders have been removed, many of us hoped for a return of the political in another form - not in the Hobbesian original form of the globalised security State, in the form of the police, secret services and now also the military, but as a civilizing, creative power worldwide. At present we have little more than the faint hope of a stratagem of reason - and a little stocktaking" [Habermas Yu., 2001].

True, one can see a glimmer of hope in the fact that the primitive man, at the very start of his journey, was able to muster his inner resources of reason and will power needed for curbing his destructive animal instincts through social creativity. So the modern man, too, may prove to be able to stop at the threshold of post-human future or walk into the new era without losing his humanity. Given these prospects for the foreseeable future, in the realm of philosophy of law, the ideas of Russian religious philosophers about all-encompassing unity, with its "anticipation of a disaster for all and the idea of salvation for all” [Gulyga A.V., 2004: 22], become especially relevant and acquire a new meaning.

\section{I国 References}

1. Andorno R. et al. (2020) Geneva Statement on Heritable Human Genome Editing: The Need for Course Correction. Trends in Biotechnology, vol. XX, pp. 1-4.

2. Berdyaev N.A. (1990) State. Power and law. In: History of Russian legal thought. Leningrad: Lenizdat, 245 p. (In Russ.).

3. Bogdanova E.E., Maleina M.N., Ksenofontova D.S. (2020) Issues of protecting civil rights in applying genomic technology. LEX RUSSICA, no. 5, pp. 129-141. (In Russ.). 
4. Cranston M. (1975) Human rights. Documents. Paris: Ed. de la Seine, $376 \mathrm{p}$.

5. Darnovsky M. (2008) Germline Modification Carries Risk of Major Social Harm. Nature, vol. 453, pp. 827-828.

6. Dickenson D. (2018) Why editing human genome is dangerous. Available at: https://forbes.kz//process/science/chem_opasno_ruchnoe_redaktirovanie_genoma_cheloveka/? (accessed: 15 February 2020)

7. Gadhikurbanova P.A. (2003) Fear and responsibility: ethics of technological civilization of Hans Jonas. Eticheskaya mysl' = Ethical Thought, no. 4, pp. 16-178. (In Russ.).

8. Grebenschikova E.G. (2016) Biotechnology and limits of human improvement. Epistemiologiya i filosofiya nauki = Epistemogia and Philosophy of Science, no. 2, pp. 34-39. (In Russ.).

9. Gulyga A.V. (2004) Introduction. Russian idea. In: The works of Russian philosophers. Moscow: Airis-press, pp. 5-24. (In Russ.).

10. Jonas H. (2004) The principle of responsibility. Moscow: Airis-press, 480 p. (In Russ.).

11. Habermas J. (2001) Belief and knowledge. Available at: https://www. gumer.info/bogoslov_Buks/Philos/Haberm/Ver_Znan.php (accessed: 12 January 2021)

12. HarariYu. N. (2019). Sapiens. A short history of humankind. Moscow: Sindbad, 278 p. (In Russ.)

13. Haslam N. (2006) Dehumanization: An Integrative Review. Personality and Social Psychology Review, vol. 10, pp. 252-264.

14. Korsani A. (2007) Capitalism, biotech science and neoliberalism. Logos, no. 4, pp. 123-143. (In Russ.).

15. Kosinski M. (2021) Facial recognition technology can expose political orientation from naturalistic facial images. Available at: https://doi. org/10.1038/s41598-020-79310-1 (accessed: 24 March 2021). (In Russ.).

16. Levandovskiy A.P. (2005) Introduction. In: Pernau R. Eloise and Abailar. Moscow: Molodaya gvardiya, pp. 6-13. (In Russ.).

17. Levi-Strauss (1985) Structural anthropology. Moscow: Nauka, 536 p. (In Russ.).

18. Lorents K. (1994) Aggression. Moscow: Progress, 272 p. (In Russ.).

19. Maslov V.M. (2014) Posthuman trends of technogenic civilization. Fundamental'nie issledovaniya=Basic Studies, no. 6, pp. 871-875. (In Russ.).

20. Milanovich B. (2014) Global inequality of profits in statistics. Moscow: HSE, 29 p. (In Russ.) 
21. Montgomery J. (2018) Modifying human genome. In: Prava cheloveka i meditsina. Moscow: Razvitie pravovykh system, pp. 42-56. (In Russ.).

22. Nazaretyan A.P. (2015) Unlinear future. Moscow: Argamak, 409 p. (In Russ.).

23. Nersesyants V.S. (2006) Philosophy of law. Moscow: Norma, 830 p. (In Russ.).

24. Nersesyants V.S. (2002) Philosophy of law. Voprosy philosofii=Issues of Philosophy, no. 3, pp. 3-15. (In Russ.).

25. O'Sullivan S. (2019) In search of balance for progress and respecting human. Prava cheloveka ш biomeditsina. Moscow: Razvitie pravovykh system, pp. 5-10. (In Russ.).

26. Podlazov A.V. (2018) Global demographics. Demograficheskoe obozrenie = Demographic Review, no. 1, pp. 39-63. (In Russ.)

27. Ponkin I., Redkina A.I. (2018) Artificial intelligence in terms of law. Vestnik RUDN = Herald of Russian University of People's Friendship, no. 1, pp. 91-109. (In Russ.).

28. Prokofiyev A.V. (2013) Protecting interests of the future generations. Vestnik Moskovskogo universiteta $=$ Herald of Moscow State Lomonosov University, no. 3, pp. 78-93. (In Russ.).

29. Rieker P. (2005) The fair. Moscow: Logos, 299 p. (In Russ.).

30. Romashov R.A. (ed.) (2021) Legal genesis: tradition, will, law. Saint Petersburg: Aleteya, 480 p. (In Russ.).

31. Schwab K., Malleret T. (2020) COVID-19: The Great Reset. Geneva: World Economic Forum, $127 \mathrm{p}$.

32. Semenov Yu. I. (2016) Marriage and family. Available at: URL: http:// www.scepsis.ru/library/id_6.html (accessed: 27 June 2020). (In Russ.).

33. Shalyutin B.S. (2011) Genesis of law as a factor of the formation of society and human. Voprosy filosofii = Issues of Philosophy, no. 11, pp. 14-26. (In Russ.).

34. Sinelnikov S.P. (2010) Christian anthropology about the image and likeness of man to God. Available at: URL: https://bogoslov.ru/ article/817555 (accessed: 5 February 2021). (In Russ.).

35. Sinchenko G. Ch. (2000) From Mitropolitan Ilarion to N.A. Berdyayev. Filosofiya prava = Philisophy of Law, no. 2, pp. 4-19. (In Russ.).

36. Stepin V.S. (2017) $21^{\text {st }}$ century as a radical transformation of civilized development. Saint Petersburg: University, pp. 185-188. (In Russ.).

37. Stepin V.S. (2011) Civilization and culture. Saint Petersburg: University, 408 p. (In Russ.). 
38. Trikoz E.N., Mustafina-Berdikhina D.M., Gulyaeva E.E. (2021) Legal regulation of procedure for gene modification. Vestnik $R U D N=$ Herald of Russian University of People's Friendship, no. 1, pp. 67-86. (In Russ.).

39. Varlamova N.V. (2020) Lockdown as a measure to response to the COVID-19 pandemic. Vestnik Saint Peterburgskogo Universiteta MVD = Herald of Saint Petersburg MVD University, no. 3, pp. 6-25. (In Russ.).

40. Waal F., Ober J. (2005) Primates and Philosophies: How Morality Evolved. Princeton: University Press, 209 p.

41. Weizsäcker E., Wijkman A. (2018) Come On! Capitalism, Shorttermism, Population and the Destruction of the Planet. A Report to the Club of Rome. New York: Springer, $232 \mathrm{p}$.

42. Woods T. (2010) How the Catholic church built Western civilization. Moscow: IRISEN, 280 p. (In Russ.).

43. Yudin B.G. (2016) Person as an object, consumer and target of technological science. Znanie. Ponimanie. Umenie=Knowledge. Understanding. Capability, no. 5, pp. 5-22. (In Russ.).

44. Zakharova M.V., Voronin M.V. (2018) Measure of Freedom in the Context of Legal Regulation of Genomic Research: Foreign Experience. Revista Dilemas contemporáneos: Educación, Política y Valores. Year VI. Available at: https://dilemascontemp.oraneoseducacionpoliticayv alores.com/_files/200004128c6b43c7b2e/EE\%2018.12.16\%20edida (accessed: 12 September 2019)

\section{Information about the author:}

V.V. Lapaeva - Doctor of Sciences (Law), Chief Researcher.

The article was submitted 12.05.2021; approved after reviewing 27.08.2021; accepted for publication 30.09.2021.

The article was published first in: "Law. Journal of the Higher School of Economics", no .3, 2021, p. 4-35. 